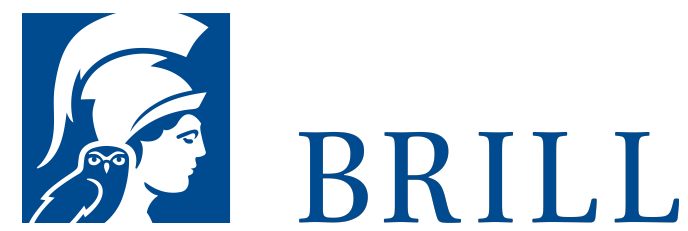

\title{
Mentale Verursachung, innere Erfahrung und handelnde Personen
}

Eine Verteidigung des Epiphänomenalismus

Author: David Hommen

Die Annahme, dass mentale Zustände wie Überzeugungen, Wünsche und Gefühle physische Ereignisse bewirken (wie körperliches Verhalten und willentliche Handlungen), ist ebenso verbreitet wie problematisch, weil sie im Widerspruch zu der Überzeugung steht, dass mentale Zustände Phänomene nichtphysischer Natur sind und physische Phänomene ausschließlich physische Ursachen haben. Der Epiphänomenalismus, der diesen als Leib-Seele-Problem bekannten Widerspruch auflöst, indem er die kausale Wirksamkeit des Mentalen bestreitet, stößt unter Laien und Philosophen jedoch auf erheblichen Widerstand. Die vorliegende Studie wendet sich den Intuitionen zu, die sich einer epiphänomenalistischen Auflösung des Leib-SeeleProblems in den Weg stellen: einerseits die innere Erfahrung unserer Urheberschaft, andererseits unser Selbstverständnis als handelnde Personen. Es wird argumentiert, dass die durch die Berufung auf diese Intuitionen zum Ausdruck gebrachten, selten jedoch ausdrücklich vorgebrachten Argumente für die These der mentalen Kausalität allesamt nicht überzeugen können. Vielmehr ist der Epiphänomenalismus sowohl mit unserer inneren als auch unserer äußeren Lebenswirklichkeit vereinbar.

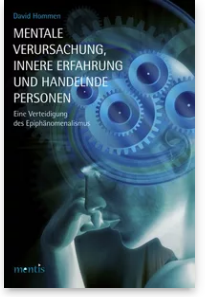

Pages: 340

Seiten

Language:

German

Subjects: 19th \& 2oth Century

Philosophy, Philosophy

Publisher: Brill | mentis

E-Book (PDF)

Released online: o1 Jul 2013

ISBN: $978-3^{-}$

89785-974-6

List price

Paperback

Publication date:

o1 Jul 2013

ISBN: 978-3-

89785-823-7

List price 
For more information see brill.com

Order information: Order online at brill.com +44330 333 0049 | customerservices@brill.com Submission information: brill.com/authors

Titles published by Brill | Fink, Brill | mentis or Brill | Schöningh: +49(o)715413279216| brill@brocom.de 